ANL- ? $0-X X-14$

\title{
AIR POLLUTION AND THE SITING OF FOSSIL FUEL POWER PLANTS
}

EMVIRONMENTAL POLLUTANTS and the URBAN ECONOMY

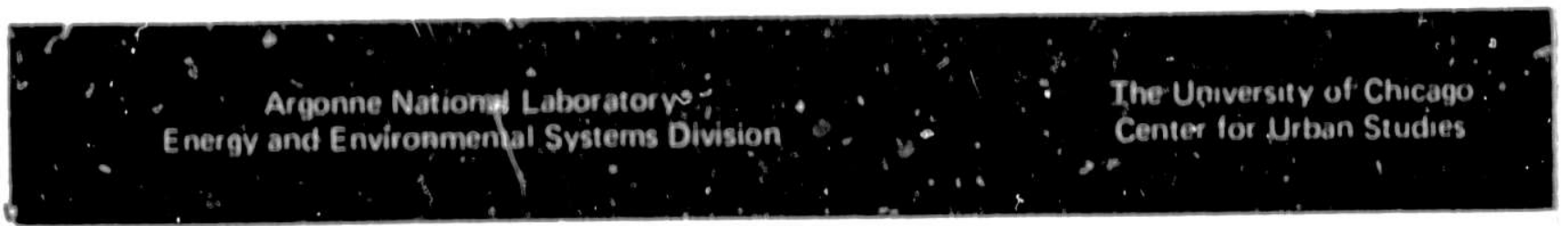


The facilities of Argonne Viational Laboratory are owned by the United States Covernment Under the termis of a contract $\left(W-31-109-\right.$ Eng- 36 ; etween the $L^{\prime} S$ Energ) Research and Development Adnunistration. Argonne Unwersatses Assoctation and The University of Chacago. the University employs the statf and operates the Laboratory in accordanor with policies and programs formulated. approved and reviewed by the Assoctation

\section{ME.MBERS CH ARGONEE L'NIVERSIIISS ASSOCLAIION}

The University of Arizon.4

Carnegie-Mellor Unuversity

Case Western Reserve Lnuversity

The University of Chicag,

University of Cincinnat!

Illinos Inotitute of Technology

University of lllinots

Indiana Universit?

Luma State Unuversity

The Cinuvirsty of lov.t
Kansas State L'nuversity The Unuversity of kansas

toyula linversity

Marquette Unuversity

Michigan State Lnuersity

The L'nuversity of Michigan

Unuersity of Minnesota

Lnaverstly of Missouri

Norihuestern Unaversity

Unisersity of Notre Dame
The Ohus State Unuversity

Ohio Unuversity

The Pennsylvania State L'uversity

?urdue University

Saint louss Un.versity

Southern Illinots Unuersity

The Unaversity of Texas al Austun

Washangtun Unaversaty

Wayne State Unuversity

The Unuverstly o! Wisconsin

\section{NOTICE}

This report was prepared as an accuunt of work sponsured by the Lnited States Government Nesther the Linsted states nor the United States Energy Research and Delelupment Administration. nor any of their employees, nor any of thes contractors, subcontractors. or thear employers. mak : any warranty. express or implied or asoun:es any legat l.abil. tty of responsibility for the accuracy. completeness or wae. fulnes of any intermation. apparatus. product or process disclosed. or represents that th use would not intringe privately-owned righto Mention of commerctal products. their manufacturers. or their suppliers in this publication does not imply or connote approval or disapproval of the preduct by Argonne National Laboratory or the U S Energy Research and Develupment Admunistration 


\section{AIR POLLUTION AND THE SITING \\ OF FOSSIL FUEL POWER PLANTS}

by

Gideon Fishelson, Gordon C. Rausser, and

Alan S. Cohen

July 1976

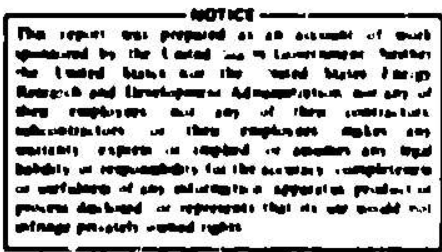

ENVIRONMENTAL POLLUTANTS and the URBAN ECONOMY

The University of Chicago Center for Urban Studies
Argonne National Laboratory Enerey and Environmental Systems Division 


\section{TABLE OF CONTENTS}

Page

THE COSTS OF SITING DECISIONS. . . . . . . . . . . . . . . . S

ANALYSIS OF SOCIAL COSTS . . . . . . . . . . . . . . . . . . 5

RESULTS OF THE ANALYSIS . . . . . . . . . . . . . . . . . . 8

SENSITIVITY OF THE RESULTS . . . . . . . . . . . . . . . . . 10

POLICY IMPLICATIONS . . . . . . . . . . . . . . . . . . . 10 


\section{AIR POLLUTION AND THE SITING OF FOSSIL FUEL POWER PLANTS}

\section{The Costs of Siting Decisions}

The decision to locate a lossil fucled electrical power plant on a particular site invelves trade-offs among the costs of: 1) land acquisition. 2) plant construction, operation. and maintenance. 3) pouer transinission. and 4) air pollution damage to humblss, animals, plants and materials. The fourth of these, pollution costs, has been of great concern in recent years. But seldom, if ever, are the specific dollar trade-offs between the environmental and the other costs associated with site selection taken into account.

Tlue surn of the costs of power generation (land, construction, operation, maintenance), power tralismission. and air pollution damages (trom sulfur dioxide, nitrogen oxides. and particulates) is the total social cost of a fossil fuel plant; ihis total cost will generally vary by site. This paper presents an analysis of the total social cost, and the trade-offs between generation/transmission and air pollution costs, jor various types of fossil plants at different sites in northeri Illinois. The analysis identifie's the combinations of site. fossil fuel, and sulfur dioxide $\left(\mathrm{SO}_{2}\right.$ ) control technology that minimize total social costs.

Analysis of Social Costs

The alternpt to select the best locations for different eypes of power plants was based upon the costs associated with generating and transmitting electricity. A complete systems optimization would also require estimates of the social costs of mining (or extracting) and transporting luels and consuming electricity. Nevertheless, this analysis provides a usefisl evaluation of the social cost of electricity generation and transmission that is consistent with both the regional focus of air pollution control programs throughout the country. and the present scope of power plant situng review procedures.

Four decision varizbles, resulting in lour design thoices to be made for each power plant. were losed in the analysis: site, stack height, boiler fuel, and sulfur dioxide emission contrcl method. The site options consisted of 5: hypothetical power plant locations. spatied about 15 miles apart. in thie nural and arban fringe areas of northern lllinois. Lach plant was assumed to Iranssnit its clecicricity to one of three lixed-lociation cons:umption centers (see Fig. I). Stacin necights were varied between 500 and $1000 \mathrm{ft}$. The fuel and sulfur dioxide control technology choices wert:

- ligh sulfur llinois coal (no $\mathrm{SO}_{2}$ control).

- Low sulfur Western coal (no SO, control).

- high sulfur lllinois coal with an $\mathrm{SO}_{2}$ scrubber.

- high sulfur vil (no $\mathrm{SO}_{2}$ control),

- low Btu gis obtained fir am an adjacent coal gasification plant.

- low sulfur oil (no SO, control), and

- high sulfur oil with an SO, scrubber. 


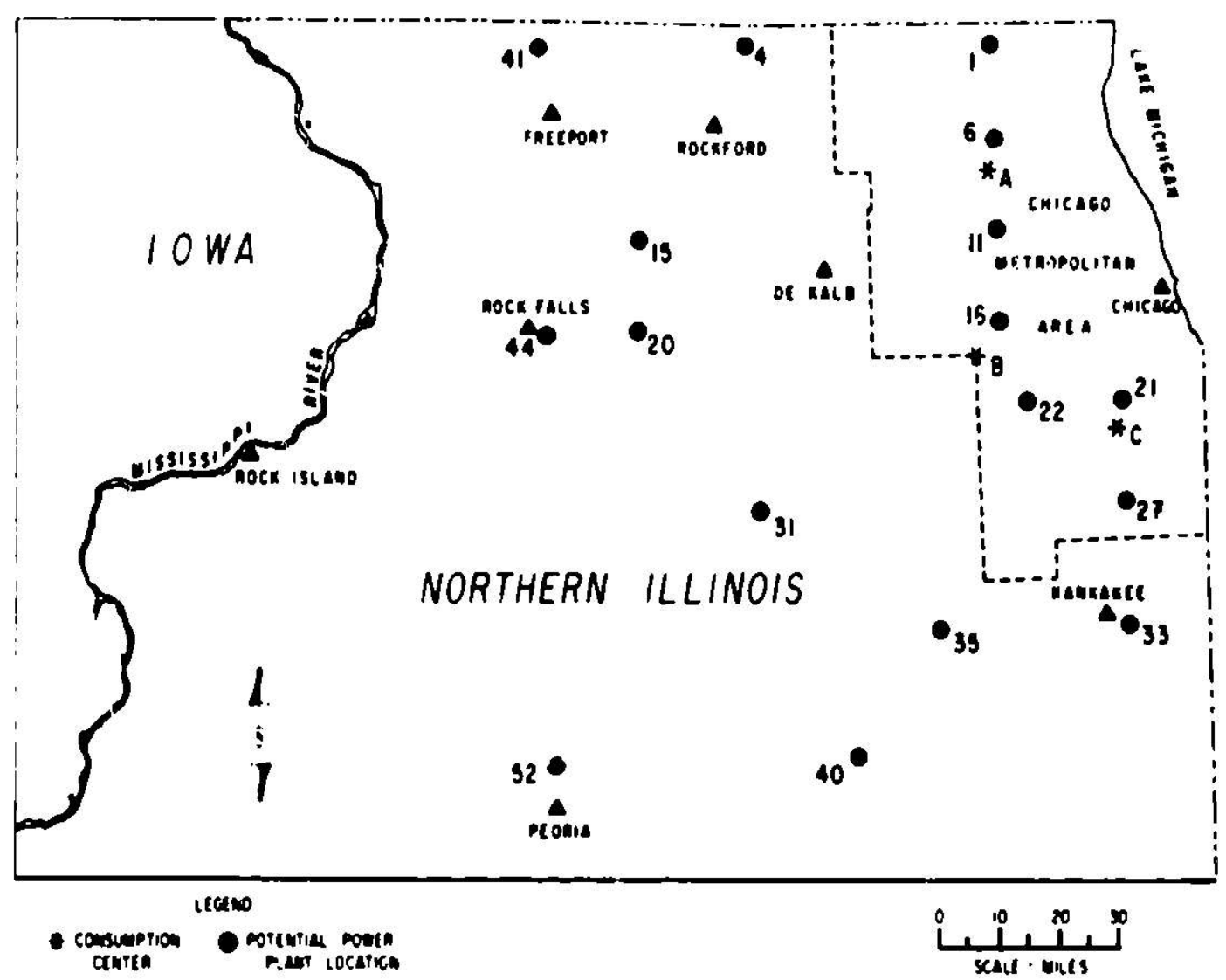

Fig. I. Study Ares.

Electrostatic precipitators for controlling particulate emissions with operating efficiencies of $99 \%$ for Illinois coul, $98 \%$ for Western coal, and 94\% for oil were assumed to be used. Also, power plants were presumed to be of a given unit size; thus, potential economies of scale of the unit size or of more than one unit within a plant were not considered. The assumed values for various plant and fuel parameters are listed in Table 1.

Air pollution damages from sulfur dioxide, suspended particulate matter, and nitrogen oxjdes were calculated using population forecasts for 1980 and damage faciors of $51.25,52.50$ and $51.00 / \mu \mathrm{c} / \mathrm{m}^{3} / \mathrm{person} /$ year. respectively. The damage factors for $\mathrm{SO}_{2}$ and particulates are about the midfange figures reported by Cohen et al.." adjusted for the 1974 price levei: the nitrogen oxides factor was calculated using the proportionality factor to sisfur dioxide as reported by Babcock and Nagda." These damage factors reflect human murtality and morbidity. und material corrosion and soiline effects of these peillutants. The magnitude of vegetation and animal damages in the study area was insignificunt, relative to the human and material damages; therefore, these damages were not explicitly considered.

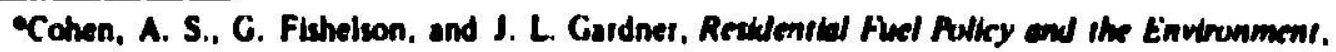
Cambridge, Mass., Ballinger Publishing Co.. 1974.

- Babcock. L. R. and N. L. Nagda, Cust Effectiveness of Eimianion Conind, Journal of the Air Pollution Control Akn., 23(3): 173-79, 1974. 
The use of constant damage factors preciudes the need to consider time-varying pollution concentrations. Therefore, these air pollution damage factors applied to annual average pollution estimates are suificient for predicting total annual damages. The use of non-linear damage functions could alter the analysis' results.

The costs of air pollution were calculated by multip!ying an estimated pollutant level by the population exposed to that level by the appropriste damage factor. Estimates of the $\mathrm{SO}_{2}$ and particulate levels were obtained using the Air Quality Display Model (AQDM). Nitrogen oxides were assumed to disperse like sulfur dioxide. Mettorological data from Chicago, Peoria, and Rockford, lllinois, were used to obtain spatial variations in meteorological conditions for the different power plant sites.

Because hypothetical rather than actual sites were analyzed, the land, labor, construstion, fucl, operating, and maintenance costs for each type of fossil fuel plant were assumed to be the same for all locations. Therefore, only transmissionrelated costs and air pollution damages were location dependent. The costs of transmission line investment, mainienance, and operation; electricity losses from the lines; and transmission line reliability were assumed to be proportional to the distance between the plant site and one of the three consumption centers. The analysis identıfies the maximum regulated distance from population centers that can be economically justified for reduction of air pollution damages. (If the costs ussumed constant do vary systematically with distance this maximum distance could be revised accordingly.) Beyond this maximum distance. the additional transmission costs would exceed any savings gained from reduced pollution damages.

TABLE I. Power Plant and Fuel Parameters

\begin{tabular}{|c|c|c|c|c|c|c|c|}
\hline & $\begin{array}{l}\text { Illinois } \\
\text { Coal }\end{array}$ & $\begin{array}{l}\text { Western } \\
\text { Coal }\end{array}$ & $\begin{array}{l}\text { Illinois } \\
\text { Cual and } \\
\text { Scrubber }\end{array}$ & $\begin{array}{l}\text { High } \\
\text { Sulfur } \\
\text { Oil }\end{array}$ & $\begin{array}{c}\text { Coal } \\
\text { Gasitication }\end{array}$ & $\begin{array}{l}\text { Low } \\
\text { Sulfur } \\
\text { Odl }\end{array}$ & $\begin{array}{l}\text { High Sulfur } \\
\text { Oil and } \\
\text { Scrubber }\end{array}$ \\
\hline \multicolumn{8}{|l|}{$\begin{array}{l}\text { Number of } \\
\text { Generating }\end{array}$} \\
\hline Units & 3 & $?$ & 3 & 5 & 3 & 5 & 5 \\
\hline $\begin{array}{l}\text { Total } \\
\text { Capacity (MW) }\end{array}$ & 2400 & 2400 & 2400 & 2500 & 2400 & 2500 & 2500 \\
\hline $\begin{array}{l}\text { Annual } \\
\text { Utilization } \\
\text { Rate/Unit (3) }\end{array}$ & 65 & 65 & 65 & 65 & 65 & 65 & 65 \\
\hline $\begin{array}{l}\text { Heat Rale } \\
\text { (Btu/kWh) }\end{array}$ & 8900 & 9350 & 9800 & 8830 & 10.700 & 4830 & 9700 \\
\hline $\begin{array}{l}\text { Fuel Price" } \\
\text { (S/10 Biu) }\end{array}$ & 0.60 & 0.40 & 0.60 & 1.25 & $0.60^{\circ \bullet}$ & 1.50 & 1.25 \\
\hline
\end{tabular}

- Prices reflect the post embargo (beejnnins: - 1974) fuel market in nosthern Illinois.

- Price of Illinuis cual fuel inpul. 


\section{Results of the Analysis}

The estimated air pollutiun damages that would be caused by each of the seven alternative power piant types located at 15 of the 52 sites considered in the analysis are shown in Table 2. Among the 15 representative locations selected for inclusion in this table are those with the most significani - i.e., maximum, minimum. optimum - pollution costs and total social costs. The maximum air pollution cost (Illinois coal at site 11 ), which is less than $2.0 \mathrm{mills} / \mathrm{kWh}$, is about $15 \%$ of the total social cost of generating electricity with Illinois coal at site II. Compurison of Table 2 with Figure I shows that damages fall quite rapidly as the plant locations shift westward into areas having relatively low population densities. For example, for llinois coal the damage is $1.91 \mathrm{mills} / \mathrm{kWh}$ at site 11 , but only $0.19 \mathrm{mills} / \mathrm{kWh}$ at site 15.

The figures in Table 2 were combined with estimates of the generation/

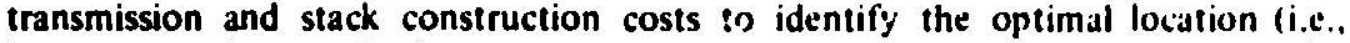
lowest sum of generation/transmission, stack construction, and pollution costs) for supplying electricity to each of the consumption centers A, B, and C. These

TABLE 2. Environmental Costs of Fussil Fueled Powar Plants * (mills/kWh)

\begin{tabular}{cccccccc}
\hline Location & $\begin{array}{c}\text { Illinois } \\
\text { Coal }\end{array}$ & $\begin{array}{c}\text { Weztern } \\
\text { Coal }\end{array}$ & $\begin{array}{c}\text { Illinois } \\
\text { Coal and } \\
\text { Scrubber }\end{array}$ & $\begin{array}{c}\text { High } \\
\text { Sulfur } \\
\text { Oil }\end{array}$ & $\begin{array}{c}\text { Coal } \\
\text { Gasification }\end{array}$ & $\begin{array}{c}\text { Low } \\
\text { Sulfur } \\
\text { Oil }\end{array}$ & $\begin{array}{c}\text { High Sulfur } \\
\text { Oil and } \\
\text { Scrubber }\end{array}$ \\
\hline 1 & 0.96 & 0.54 & 0.62 & 0.34 & 0.29 & 0.16 & 0.21 \\
4 & 0.43 & 0.24 & 0.28 & 0.15 & 0.13 & 0.07 & 0.09 \\
6 & 1.39 & 0.79 & 0.89 & 0.49 & 0.43 & 0.23 & 0.30 \\
11 & 1.91 & 1.08 & 1.23 & 0.67 & 0.59 & 0.32 & 0.41 \\
15 & 0.19 & 0.11 & 0.12 & 0.07 & 0.06 & 0.03 & 0.04 \\
16 & 1.82 & 1.03 & 1.17 & 0.64 & 0.56 & 0.31 & 0.39 \\
20 & 0.15 & 0.09 & 0.11 & 0.06 & 0.05 & 0.03 & 0.04 \\
21 & 1.65 & 0.93 & 1.45 & 0.58 & 0.50 & 0.28 & 0.35 \\
22 & 1.59 & 0.90 & 1.02 & 0.56 & 0.49 & 0.27 & 0.34 \\
31 & 0.17 & 0.10 & 0.11 & 0.06 & 0.05 & 0.03 & 0.04 \\
35 & 0.27 & 0.16 & 0.18 & 0.10 & 0.08 & 0.05 & 0.06 \\
40 & 0.11 & 0.06 & 0.07 & 0.04 & 0.03 & 0.02 & 0.02 \\
41 & 0.16 & 0.09 & 0.10 & 0.06 & 0.05 & 0.03 & 0.03 \\
44 & 0.11 & 0.06 & 0.07 & 0.04 & 0.03 & 0.02 & 0.02 \\
52 & 0.10 & 0.05 & 0.06 & 0.03 & 0.03 & 0.02 & 0.02 \\
\hline
\end{tabular}

-For 1980 population and stack height of 500 feet. 
locations were found to be sites 15,31, and 35 , which are 56.7 45.2, and 44.6 miles from their respective consumption centers (sete $F$. 1). The total social costs were estimated to be $14.79,14.64$, and $14.73 \mathrm{mills} / \mathrm{kWh}$, respectively. This finding was based on a $65 \%$ annual utilization rate assumed for all fossil power plants. If the utilization rate is allowed to range between 55 and $75 \%$, the social costs of these three optimal locations vary from 13.44 to $16.44 \mathrm{mills} / \mathrm{kWh}$ - the higher the utilization rate, the lower the social costs. Changing the utilization rate did not alter the optimal locations, stack heights, fuel, or $\mathrm{SO}_{2}$ control choices.

Social costs also vary with changes in the four decision variables - site. stack height. fuel, $\mathrm{SO}_{2}$ control method - used in the analysis. When Illinois coal (no scrubber) and a $500 \mathrm{ft}$ stack are used. th: maximum deviations of total social costs between all locations are $1.30,1.48$ and $1.59 \mathrm{mills} / \mathrm{kWh}$, respectively, for consumption centers $A, B$, and $C$ - a rane that represents less than $11 \%$ of the total social cost of supplying electricity with Illinois coal. If, however, stack heights are allowed to vary, the differcice in social costs among locations is even smaller: a maximum of 0.76 mills/kWh, or less than $6 \%$ of the social cost. The difference in social costs is reduced when stack heights are varied because the optimal stack height for Illinois coal plants increases as the sites move closer to population centers. The optimal stack height at site II, for ex smple, is $1.000 \mathrm{ft}$.

The variability in social cosis for different fuel/sultur dioxide control choices is significantly greater than for lociation and stack height changes. Table 3 shows the estimated differenct in total social costs of the various plant types at those locations whes' the use of Illinuis coal is the least altractive (most expensive), i.e., those sites closest to the Chicugo metropolitan area. (A stack height of $500 \mathrm{ft}$ was assumed for this table, which maximizes Illinois coal costs and minimizes the difference between

TABLE 3. Differential Soxial Costs of Various Fossil Fueled Power Planis (milts/kWh)

\begin{tabular}{|c|c|c|c|c|c|c|c|}
\hline Location & $\begin{array}{l}\text { Illinois } \\
\text { Coal }\end{array}$ & $\begin{array}{l}\text { Western } \\
\text { Coal }\end{array}$ & $\begin{array}{l}\text { Illinois } \\
\text { Coal and } \\
\text { Scrubber }\end{array}$ & $\begin{array}{c}\text { High } \\
\text { Sulfur } \\
\text { Oil }\end{array}$ & $\begin{array}{c}\text { Coal } \\
\text { Gasification }\end{array}$ & $\begin{array}{l}\text { Low } \\
\text { Sulfur } \\
\text { Oil }\end{array}$ & $\begin{array}{l}\text { High Sulfur } \\
\text { Oil and } \\
\text { Sirubber }\end{array}$ \\
\hline & $\begin{array}{l}\text { Total Sixial } \\
\text { Cost } \\
\end{array}$ & \multicolumn{6}{|c|}{ DifTerential ${ }^{\circ}$ Social Cost } \\
\hline $\mathbf{1}$ & 15.18 & $3.0 \times 20(x)$ & $3.76(25 \%)$ & $3.98(26 \%)$ & $4.73(31 x)$ & $6.00(40 x)$ & $7.75(51 x)$ \\
\hline 6 & 15.44 & $2.40(10.5)$ & $3.60(23 \pi)$ & $3.70(24 \%)$ & $4.44(29 \pi)$ & $5.64(37 \%)$ & $7.41(487)$ \\
\hline 11 & 16.01 & $2.67(189 i)$ & $3.42(21 \%)$ & $3.36(21 \%)$ & $4.08(25 \%)$ & $5.21(33 x)$ & $7.00(44 \%)$ \\
\hline 16 & 15.88 & $2.71(179)$ & $3.45(229)$ & $3.42(229)$ & 4.142651 & $5.29(337)$ & $7.07(45 \%)$ \\
\hline 21 & 15.70 & $2.78(187)$ & $3.50(23)$ & 3.5 .42271 & $4.25(27 x)$ & $5.43(35 \%)$ & $7.20(46 \%)$ \\
\hline 27 & 15.18 & $3.60(247)$ & $4.70(31 \%)$ & $3.7425 \%$ & $4.70(31 \%)$ & $3,94(26 \%)$ & $5.96(39 \%)$ \\
\hline 3.3 & 15.11 & $\left.3.16(1)^{1}\right)$ & $3.82(25 \%)$ & $4.0927 \%)$ & $4.86(32 x)$ & $6.15(41 x)$ & $7.89(52 \%)$ \\
\hline
\end{tabular}

The difference is the excial cost of using the indicated technology less the social cont of using Illinois cod. 
Illinois coal and competing fiel $/ \mathrm{SO}_{2}$ control options.) Table 3 indicattes that the use of Illinois coal, without an $\mathrm{SO}_{2}$ scrubber, results in the lowest total social cost at all locations. This is also true for the other 45 sites considered in the analysis but not included in the table. The use of Western coal, the nest most attractive alternative. would risult in a minimum increase in social costs of $17 \%$.

\section{Sensitivity of the Results}

A number of parametric analyses were performed to test the sensitivity of the conclusion that the use of Illinois coal minimizes total social costs for all the locations considered in the study. To illustrate the types of parameter changes required to alter this conclusion, consider a plant with a $500 \mathrm{ft}$ stack iocated at site 11. The air pollution damage factors would have to be more than four times as great as those used in the analysis before lllinois coal burned witt.out $\mathrm{SO}_{2}$ controls would not minimize social costs. In that case. Western coal would become the best option.

Without increasing the damage factors, the cost differences in mills $/ k$ Wh between Illinois coal and Westem coal, high sulfur oil, and low sulfur oil would have to be reduced by more than $88 \%, 58 \%$ and $65 \%$, respectively, before the use of these fucls would result in total social costs less than those of Illinois coal.

The capital costs of a coal gasification plant would have to be reduced by mon than $76 \%$ (to less than $\$ 40 / \mathrm{kW}$ ), and its operating and maintenance costs reduced by more than $40 \%$ before coal gasification would become superior to Illinois coal." The parametric changes required to make the scrubber uption. regurdless of fuel. economically justified are so extreme that it is unlikely that this option could ever be optimal in the Chicago area.

The above analyses indicate that the conclusion that Illinois ceal. with no $\mathrm{SO}_{2}$ conirols, is the best boiler fuel to be used in rural and urban fringe power plants located in northern Illinois is robust. The result is further strengthened when one considers the fact thit the above analyses are for a plant lecated relatively close to the Chicago metropolitan area with a relatively short stack. The superiority of llinois coal increases for plants further from the populated area and/or for plants with taller stacks.

\section{Policy Implicutions}

The results of this analysis indicate that appropriate horizontal and vertical displacement of power p!ant emissions can minimize the local social costs of power generation and transmission in the northern Illinois ares (assuming the particulate controls described on paye 6). Furthermore. the environmental damage differential between altemative power plant siles in rural areus is a small percintage fless than $6 \%$ ) of the total social costs of generating electricity. Forcing power plants to locide more than 60 miles from the boundaries of the Chicago metropolitall ares in order to reduce air pollution damages also would most likely not be an cconomically desirable air pollution/land use policy, since at that point. the added transmission costs would exceed any pollution damage savings.

-Other combinations of changes in capital, operating and maintenance, and fuel penalty parameten could make the coal gasification opition superiur to the Illinois coal option. but a reduction in capital costs alone would be insufficient. 


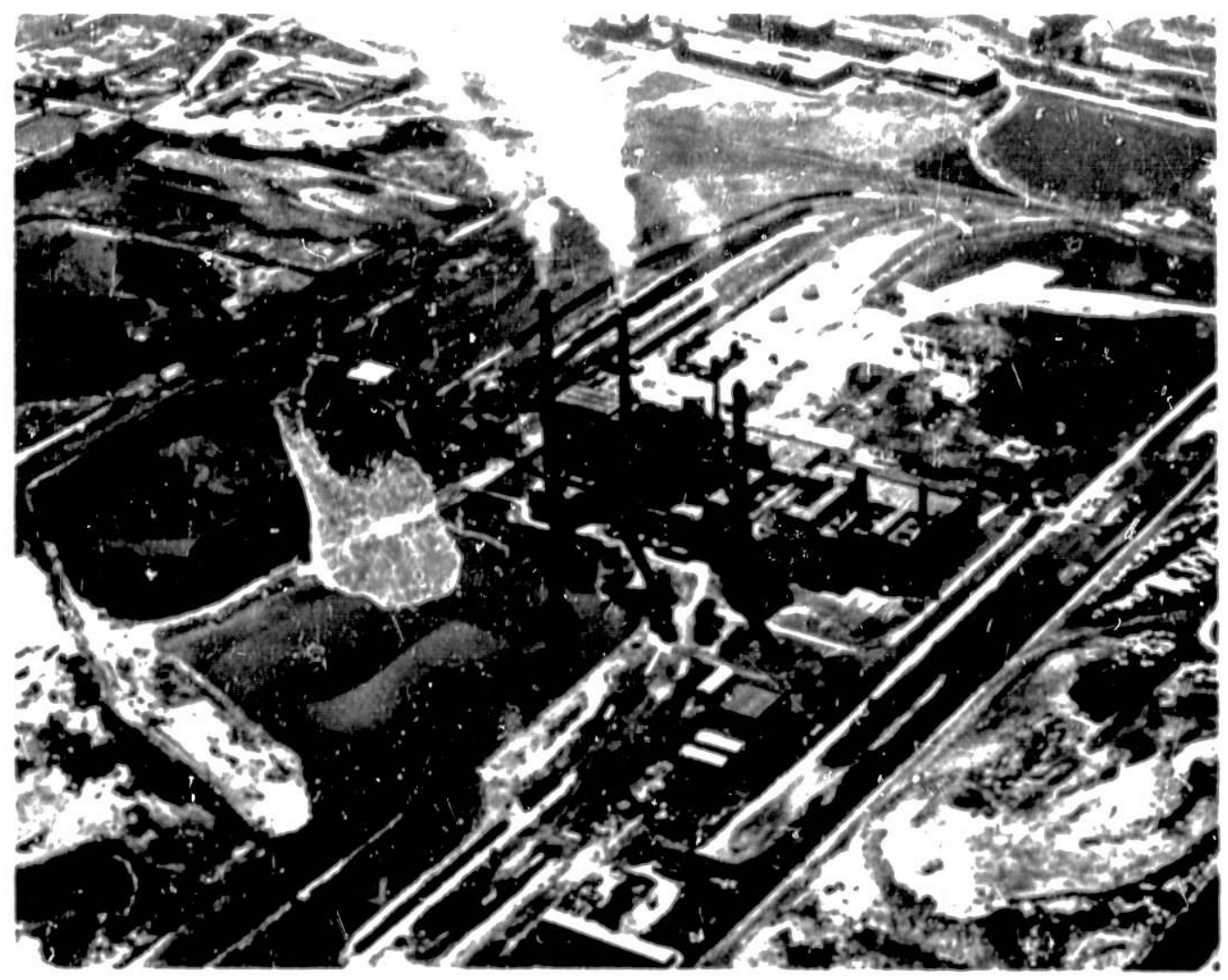

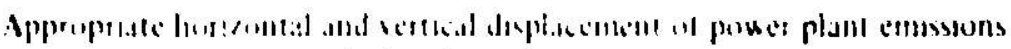

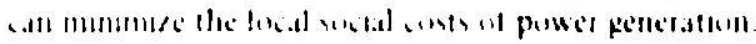

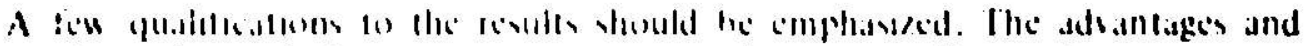

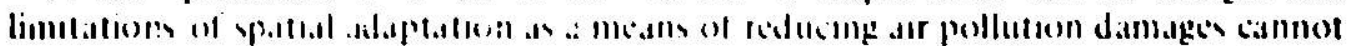

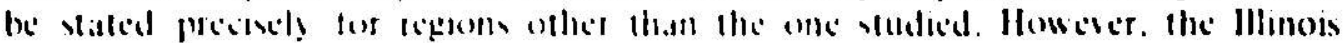

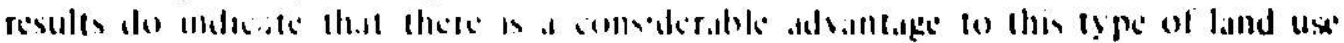

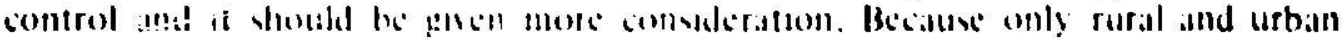

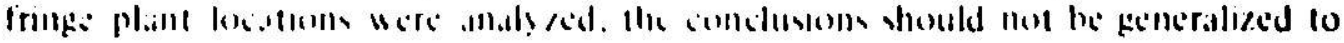

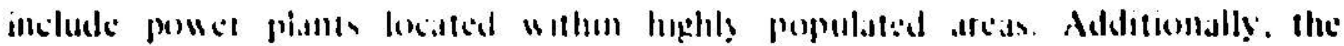

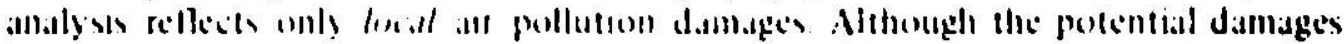

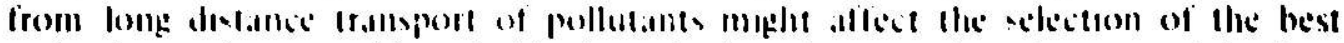

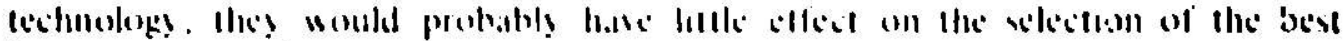
locidtust withut the study arcit.

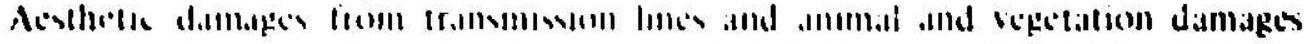

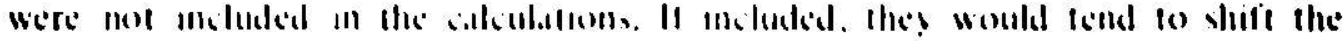

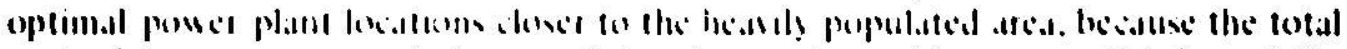

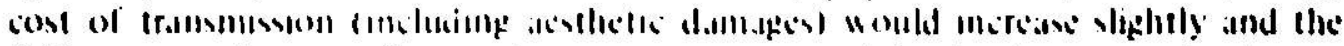

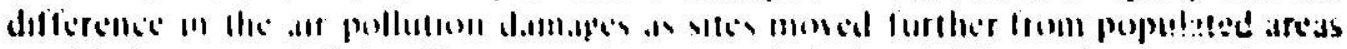

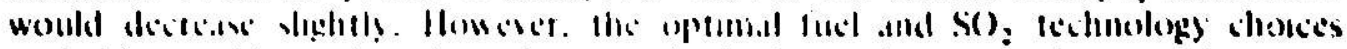

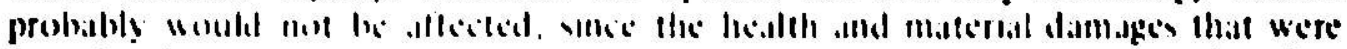

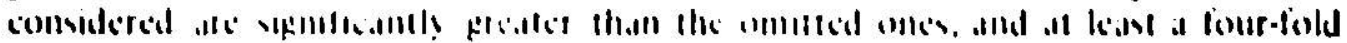

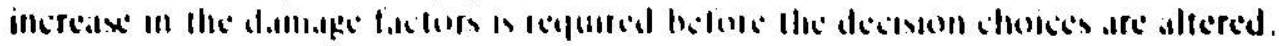


For further information on the study described in this teport, please contact:

\author{
Dr. A. S. Cohen \\ Argonne National Laboratory \\ Energy and Environmental Systems Division \\ 9700 South Cass Avenue \\ Argonne. Iltinois 60439
}

or

Prof. G. S. Tolley

The University of Chicago

Department of Economics

1126 East S9ih Street

Chicago. Illinois 60637 